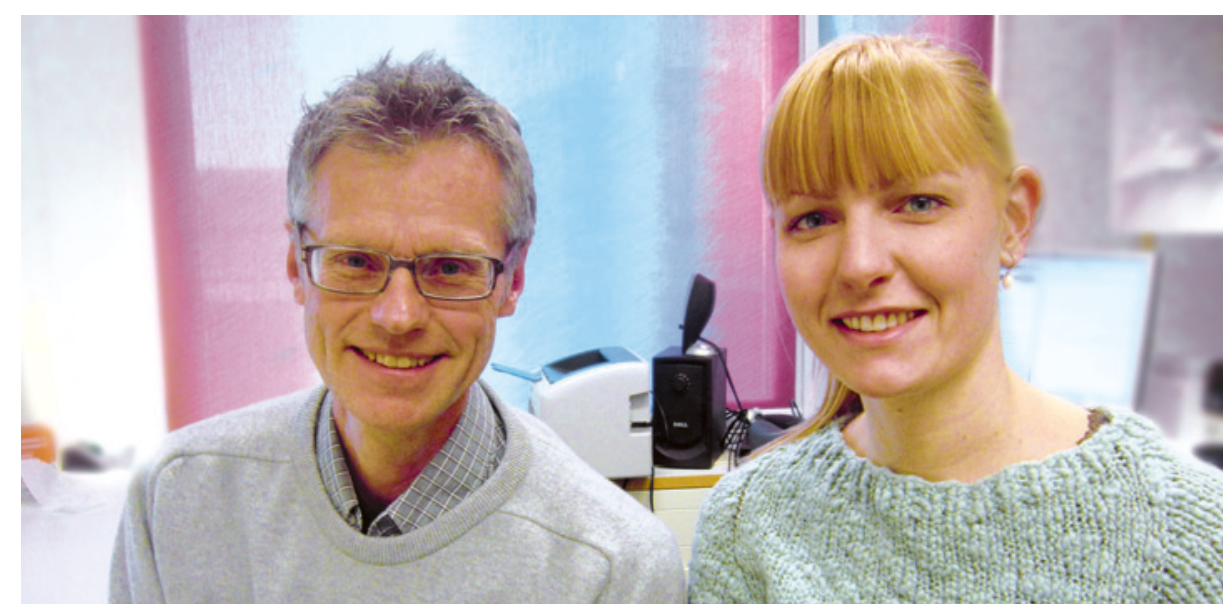

Peter 0. Hofgaard og Henriette Cecilie Jodal har delt førsteforfatterskap på artikkelen i PLoS One. Foto privat

\title{
Ny musemodell for myelomatose
}

\author{
Norske forskere har utviklet en musemodell for myelomatose. \\ En forskerlinjestudent er førsteforfatter.
}

Myelomatose rammer rundt 350 mennesker årlig i Norge, og det finnes ingen kurativ behandling. Musemodeller er mye brukt for å studere hvordan kreft virker på kroppen og hvordan immunforsvaret responderer. Det finnes flere modeller for myelomatose, men de fleste av disse kommer til kort på ett eller flere områder, f.eks. fordi musestammer er vanskelig tilgjengelige, fordi man ikke kan følge tumorveksten underveis eller fordi sykdommen ikke likner myelomatose hos mennesker.

En veletablert musemodell, MOPC315modellen, har lenge vært brukt til å studere immunsystemets reaksjon på kreft, men MOPC315.4-modellen, som er den mest brukte varianten, er blitt kritisert fordi den kun vokser subkutant. Norske forskere har derfor videreutviklet denne cellelinjen og etablert en ny cellelinje som kalles MOPC315.BM.

- Ved intravenøs injeksjon i en lett tilgjengelig musestamme gir MOPC315.BM en myelomatoseliknende kreftsykdom, med spredning til rød beinmarg, sier forskerlinjestudent Henriette C. Jodal. - Vi studerte dette ved å merke MOPC315.BM-cellene med luciferase, slik at veksten kan bli monitorert med regelmessig fotografering in vivo, sier hun.

- I tillegg kan cellenes utskilling av spesifikke immunglobuliner måles i serum. Sykdommen utvikler seg relativt raskt. Allerede innen to timer etter injeksjonen kan kreftcellene observeres i beinmargen, og alle musene utvikler paraplegi i løpet av 3-4 uker pga. ryggmargskompresjon. På samme måte som myelomatose gjør hos mennesker, gir MOPC315.BM utbredt osteolytisk sykdom hos mus.
Den nye musemodellen er lett tilgjengelig, utvikler seg raskt og er lett å monitorere for myelomatose. Den åpner muligheten for å studere sykdomsmekanismer, immunforsvar, osteolytisk sykdom og testing av nye behandlingsalternativer, sier Jodal.

\section{Forskergruppen}

Modellen er utviklet av Bjarne Bogens forskningsgruppe ved Senter for immunregulering, Immunologisk institutt, Oslo universitetssykehus, Rikshospitalet. Artikkelen er utarbeidet gjennom et samarbeid med mange europeiske forskergrupper som er interessert $\mathrm{i} a ̊$ få utviklet og benytte seg av en bedre musemodell for myelomatose. Artikkelforfatterne er Peter O. Hofgaard, Henriette C. Jodal, Kurt Bommert, Bertrand Huard, Jo Caers, Harald Carlsen, Rolf Schwarzer, Nicole Schünemann, Franziska Jundt, Mona M. Lindeberg og Bjarne

Bogen.

Bjarne Bogens forskergruppen er særlig opptatt av T- og B-cellers betydning for autoimmune sykdommer og kreft, foruten utvikling av nye vaksinemolekyler. En del av gruppens aktivitet dreier seg om myelomatose, MOPC315-modellen og immunsystemets respons på denne.

\section{Erlend Hem}

erlend.hem@medisin.uio.no

Tidsskriftet

\section{Litteratur}

1. Hofgaard PO, Jodal HC, Bommert K et al. A novel mouse model for multiple myeloma (MOPC315.BM) that allows noninvasive spatiotemporal detection of osteolytic disease. PLoS ONE 2012; 7: e51892
Ordforklaringer

Myelomatose: Beinmargskreft, en monoklonal ekspansjon av plasmaceller

MOPC: Mineral Oil Induced Plasmacytoma Luciferase: Enzym som bryter ned luciferin, et bioluminescerende protein 